\title{
Prototype of Automatic Frequncy Control in Microhydro Power Plant with Dummy Load Based on Arduino Uno and Labview
}

\author{
Medilla Kusriyanto ${ }^{1)}$, Handry Setya Utama $^{2)}$, Irfan Effendi ${ }^{3)}$ \\ Department of Electrical Engineering, Faculty of Industrial Technology, Islamic \\ University of Indonesia ${ }^{1,2,3)}$ \\ Jl. Kaliurang Km. 14.5, Sleman, Yogyakarta, 55888, Indonesia \\ Email: medilla@uii.ac.id ${ }^{1)}$,14524106@students.uii.ac.id ${ }^{2)}$,101002207@uii.ac.id ${ }^{3)}$
}

\begin{abstract}
Micro hydro power plants are small-scale power plants that use hydropower as their driving force. Hydropower can come from irrigation channels, rivers or natural waterfalls, which are used by utilizing the waterfall height (head) and the amount of water discharge. The main components of this plant are the turbine and generator. The load on the micro hydro generator will affect the value of the voltage and frequency generated. This research attempts to make a micro hydro generator with automatic frequency control using dummy load in the form of inductance which is obtained using variac. The generator output voltage and current will be read by Arduino as a control center using the ZMPT101B AC voltage sensor and ACS712 current sensor. The generator output frequency is read by reading the travel time of 1(one)full wave. This research is also equipped with a variable monitoring system for micro hydro generator using Labview. From the observations of the research data, it was revealed that the frequency output of the micro hydro generator with an automatic dummy load controller was close to the value of the mesh frequency, namely $51-52 \mathrm{~Hz}$.
\end{abstract}

Keywords: Micro hydro generator, dummy load, frequency, labview

\section{Introduction}

Micro-hydro or Micro-hydro Power Plant (MHPP) is a power plant which uses hydropower as its driving force such as irrigation channels, rivers or natural waterfalls by utilizing the head and the amount of water discharge. PLTMH is used to meet energy needs in line with the increasing human need for huge electrical energy. However, it is not balanced with the distribution of electricity networks, especially in remote areas, such as in mountainous areas that have high water potential.

Micro hydro power plants are an efficient and reliable form of clean, renewable energy. These generators can be an excellent method of harnessing renewable energy from creeks and streams. The micro-hydro plant is designed to be a run-of-river type, as it requires little without a reservoir to power the turbine. The water will flow directly through the turbine and back into the river to be used for other purposes. The plant has minimal environmental impact on the local ecosystem. The procedure for designing a micro hydro power plant is implemented with the Matlab Simulink computer program to calculate all design parameters. The choice of turbine type depends primarily on the head and flow rate. Turbine power and speed are directly proportional to site head, but there are specific points for maximum turbine power and speed with variations in site water flow rate $(\mathrm{N}$, Abdullah, 2013).

The problem that often occurs in micro hydro generating systems is that the generator frequency is not constant. It is due to changes in the connected load which causes frequent system frequency fluctuations which can cause damage to electrical equipment. Therefore, 
Load Frequency Control (LFC) is used for regulation, the frequency can be more. To obtain optimal control parameters in a micro hydro power plant system, an Artificial Intelligence (AI) is employed, which is the Adaptive Neuro Fuzzy Inference System (ANFIS) method. ANFIS data is obtained from PID controller training data. (Andik, Farul, Cahyono \& Rukslin, 2018).

The use of micro-hydro power plants is increasingly being chosen, because it has advantages economically, technically, and is environmentally friendly. The operation of micro-hydro requires the right control technology. Micro hydro is very suitable for use in areas that are difficult to reach by the electricity grid. A common problem with micro-hydro systems is unstable turbine rotation, which is caused by changes in load from consumers. It causes changes in frequency fluctuations in the system which can cause damage from the factory side and from the consumer electrical equipment side. Therefore, this research will discuss the load frequency control strategy based on Capacitive Energy Storage (CES). CES is a device that can store energy quickly and release energy within a certain time. In its use, proper adjustment of the CES parameters is required to get the optimal CES parameters on the artificial intelligence method based on micro hydro Flower Pollination Algorithm (FPA)(Ali, Djalal, Fakhrurozi, Kadaryono, Budiman \& Ajiatmo, 2018).

Superconducting magnetic energy storage (SMES) and energy storage capacitor (CES) are devices that can store energy in the form of a fast magnetic field in the superconducting coil. For optimal performance, it is necessary to adjust the SMES and CES parameters optimally. Artificial intelligence method, Cuckoo Search Algorithm (CSA) is used to obtain optimal parameters in the micro hydro system. The simulation results show that the application of CSA which is used to tune the SMES-CES-PID hybrid parameter can reduce the oscillation overshoot frequency response in micro hydro power plants (Djalal, Setiadi \& Imran, 2017).
Frequency control strategies in micro hydro power plants using Capacitive Energy Storage (CES) are discussed in this study. To optimize CES performance, proper settings are needed to optimize CES performance. To get the optimal CES parameters for micro-hydro, an artificial intelligence method based on the Imperialist Competitive Algorithm (ICA) is used (Djalal, Yunus, Imran \& Setiadi, 2018).

The performance of the PLTMH generator load controller was tested using software simulation. Matlab is used for simulation purposes. Based on the simulation results of 47 samples of consumer load power variations, it can be concluded that the generator load controller designed in this study worked quite well. Generator load controllers always manage to control the distribution of power to the load balancing which results in the generator still operating at full load $(36 \mathrm{~kW} \pm 1.2 \%)$ even though there are power fluctuations in consumer loads (Hafid, 2021).

Application Control Neural Network (ANN) with feedback from the generator output frequency is employed to regulate the stability of the generator rotation. ANN will be able to produce the appropriate output for the learning process based on the weights of the input neurons, frequency, rotation, and altitude level to be able to control the microcontroller to move the water turbine regulator, so that it can compensate for load changes at stable frequencies at $50 \mathrm{~Hz}$ and voltage of $220 \mathrm{VA}$ (Jasa \& Heri, 2010).

A comprehensive literature survey on load frequency control in micro-hydro power plants and aims to present a fuzzy logic-based controller design that will manage almost all of the generating unit operations is discussed in this paper. The presented fuzzy logic-based controller has three main tasks. First, it regulates the generator output frequency despite changes in user load. Second, limiting the wastage of available water. Lastly, it manages the distribution of electricity by dividing the mini grid at various connected departures in order of priority (Kamble \& Akolkar, 2018).

Indonesia has many civilizations without electricity in remote areas. To meet the high 
demand for electricity, low cost and environmentally friendly power plants that reach remote areas are needed. Micro hydro power plant is proposed as a solution that can penetrate the limited accessibility for transportation, technology, and cost (Marliansyah, Putri,Khootama \& Hermansyah, 2018)

This research discusses the Sliding Mode control designer to solve LFC problems in micro hydro power plants. To design this control, a mathematical model is derived from the system and further simplified. Based on this model, Sliding Mode control is designed (Qian, Tong \& Liu, 2018).

The Hydraulic Regulator (HG) in a SelfSufficient Micro Hydro Generation System (SMHS), in order to keep voltage and frequency at desired levels, is undesirable because HG is much more expensive than generators. An electronic load controller (ELC) is a costeffective solution for this application. A resistive load of the same generator rating is used to maintain a constant voltage and frequency at the load. The system receives electrical and mechanical stresses while operating at full load over its lifetime leading to component degradation and reduced service life. (RajaSingh, Kumar, Shruthi, Panda \& ThangaRaj, 2018).

The majority of micro-grid systems are isolated from the grid and to ensure voltage and frequency stability at different loads a good control system is required. A new approach with Synchronous Generator in Electronic Load Controller (ELC) is discussed here. The ELC design was tried using an uncontrolled bridge rectifier, the chopper using IGBT was designed to control resistive loads (Sanampudi \& Kanakasabapathy, 2021).

The use of the Electronic Load Controller on micro hydro is a power setting that does not require a separate penstock to control the speed of water flow. The ELC maintains a constant generator output by introducing a separate load called a ballast load that absorbs the load required by the consumer. The apparent load used in this research is the resistor in series (Wube, 2016).

This study attempted to make automatic frequency control using Arduino as a control center and an apparent load in the form of an inductor obtained from a variac. The system is also equipped with a monitoring system to see the value of voltage, current, frequency, and water rotation speed.

\section{Methodology}

\subsection{Hardware Design} follows:

The hardware design in this study is as 


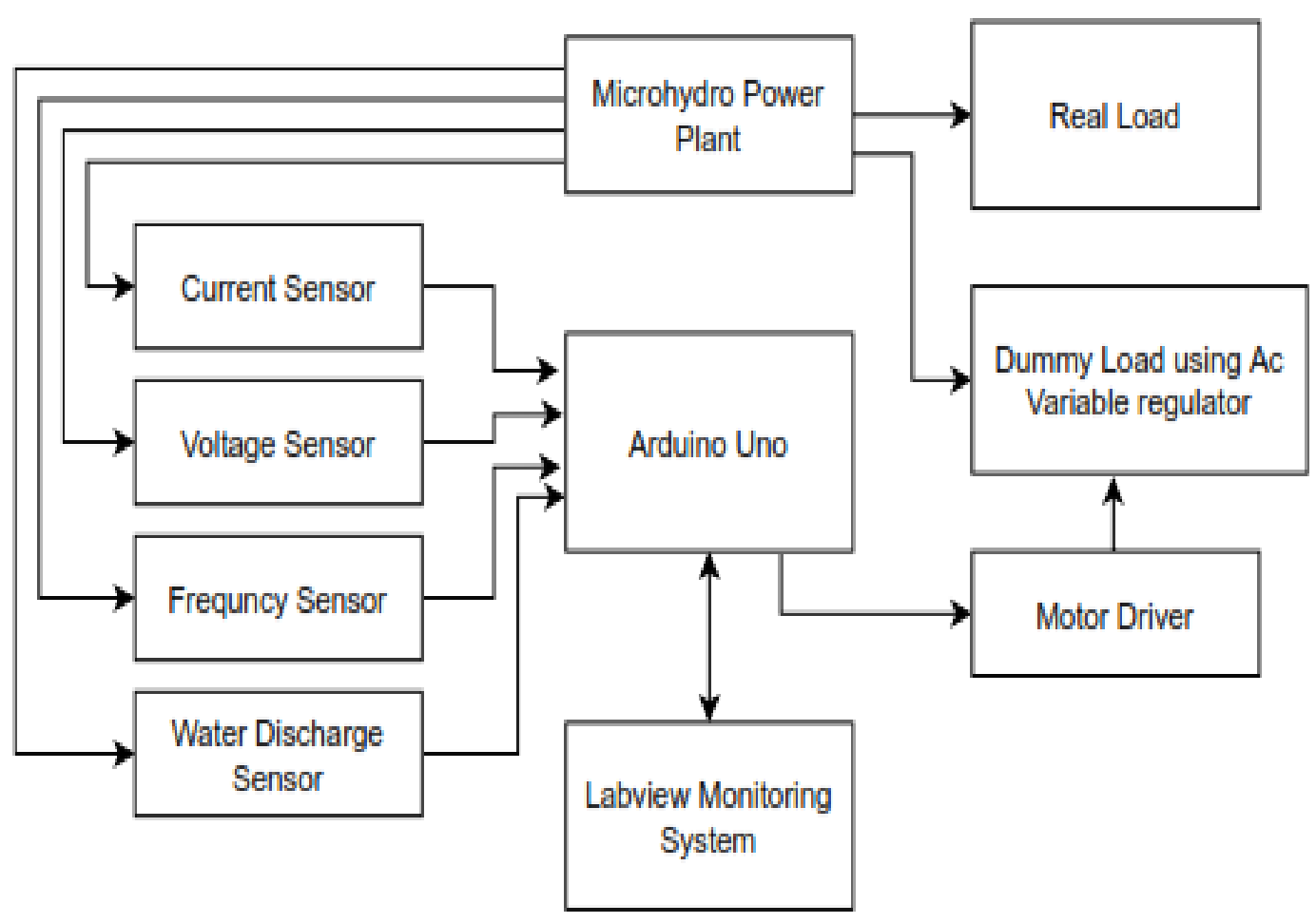

Figure 1. Micro hydro Prototype Monitoring and Control Design

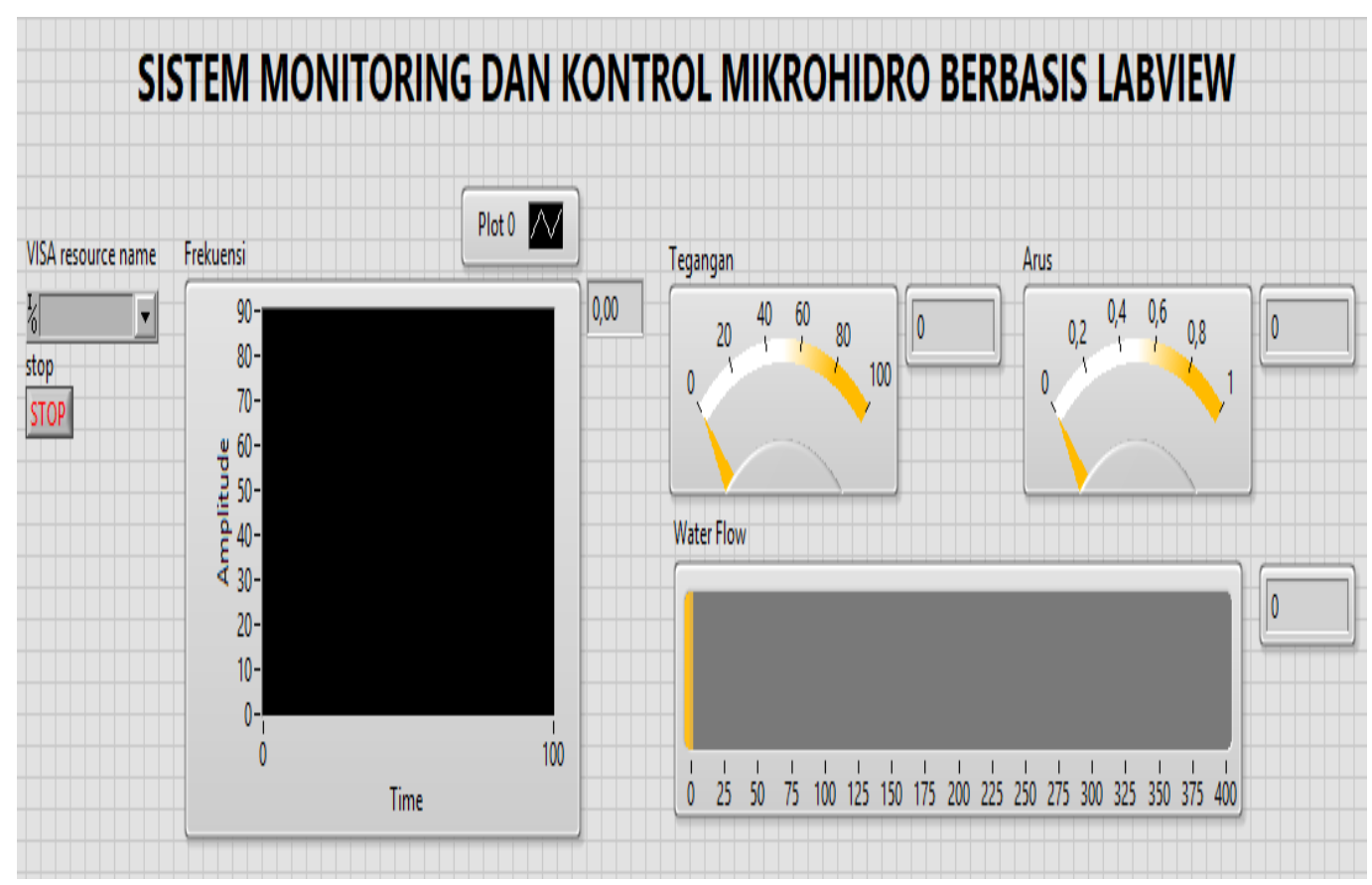

Figure 2. Front Panel pada LabVIEW

In this study, a frequency setting was developed using a variac coupled to a dc motor as shown in Figure 1. This load is connected in parallel with the main load of the micro hydro generator. Arduino will read the current, voltage, frequency and water discharge values 
to be displayed in the monitoring system using Labview. Frequency changes caused by load changes will be controlled by sending a PWM signal to the dc motor through the L298 D motor drive to adjust the apparent load so that the frequency is stable.

Arduino will read the generator output voltage value using the ZMPT101B AC voltage sensor, the generator output current with the ACS712 current sensor. Arduino will also read the water discharge as the main mover and the generator output frequency as the main variables in this study. The frequency is read by calculating the output waveform from the generator. This data will be sent to Labview via serial communication. The frequency value will be compared with the PLN network frequency. If the generator output frequency is not the same as the PLN mesh output frequency, then Arduino will send a PWM signal and the direction of rotation to the $\mathrm{L} 298 \mathrm{D}$ drive to vary the apparent load in the form of variacs to get the same frequency as the PLN mesh frequency, which is $50 \mathrm{~Hz}$.

\subsection{Software Design}

The design of the software in this study is divided into 2 software, which are Arduino and LabView. Arduino programming is used to read variables in the micro-hydro generator as well as adjust the micro-hydro output frequency. LabView is used to design a micro hydro generator monitoring system. Figure 2 is a form of monitoring system.

\section{Results and Discussion}

\subsection{Testing the Voltage and Current of a Micro-Hydro Generator}

In this study, a prototype of a micro hydro generator was used with an output voltage of 100 volts and a current of 1 ampere. At the maximum water flow, which was $364 \mathrm{~L} /$ hour, a frequency of 135 Hertz was obtained. The sensors in this study were calibrated using a linear regression equation. The test results were shown in Table 1 and Table 2.
Table 1. Voltage Sensor Test Results

\begin{tabular}{cccc}
\hline ADC \\
Value & $\begin{array}{c}\text { Multimeter } \\
\text { Voltage } \\
\text { Value } \\
(\mathrm{V})\end{array}$ & $\begin{array}{c}\text { Sensor } \\
\text { Voltage } \\
\text { Rated } \\
(\mathrm{V})\end{array}$ & $\begin{array}{c}\text { Error } \\
(\mathrm{V})\end{array}$ \\
\hline 518 & 10 & 11,479 & 1,479 \\
522 & 20 & 19,458 & 0,541 \\
527 & 30 & 29,431 & 0,568 \\
532 & 40 & 39,405 & 0,594 \\
537 & 50 & 49,378 & 0,621 \\
542 & 60 & 59,352 & 0,647 \\
547 & 70 & 69,325 & 0,674 \\
552 & 80 & 79,299 & 0,700 \\
557 & 90 & 89,272 & 0,727 \\
562 & 100 & 99,246 & 0,753 \\
\hline
\end{tabular}

from table 1 , it is shown that the voltage value read on the Arduino is with an average error of 0.594 volts.

Table 2. Current Sensor Test Results

\begin{tabular}{cccc}
\hline $\begin{array}{c}\text { ADC } \\
\text { Value }\end{array}$ & $\begin{array}{c}\text { Multimeter } \\
\text { Value } \\
(\mathrm{A})\end{array}$ & $\begin{array}{c}\text { Sensor } \\
\text { Value } \\
(\mathrm{A})\end{array}$ & $\begin{array}{c}\text { Error } \\
(\mathrm{A})\end{array}$ \\
\hline 520 & 0 & 0,029 & 0,029 \\
531 & 0,26 & 0,245 & 0,014 \\
543 & 0,51 & 0,481 & 0,028 \\
557 & 0,76 & 0,757 & 0,002 \\
566 & 0,93 & 0,934 & 0,004 \\
574 & 1,09 & 1,091 & 0,001 \\
580 & 1,2 & 1,210 & 0,010 \\
\hline
\end{tabular}

from table 2, it is shown that the current value in the micro hydro generator is read by Arduino with an average error of 0.022 Ampere.

\subsection{Testing the generator with a load of $R$}

The test was conducted by installing a load of $\mathrm{R}$ on the micro hydro generator without using dummy loads. The test results are shown in Table 3 . 
Table 3. Test results with load $\mathrm{R}$

\begin{tabular}{ccc}
\hline $\begin{array}{c}\text { Frequency } \\
(\mathrm{Hz})\end{array}$ & $\begin{array}{c}\text { Voltage } \\
(\mathrm{V})\end{array}$ & $\begin{array}{c}\text { Current } \\
(\mathrm{A})\end{array}$ \\
\hline 80 & 61,00 & 0,32 \\
80 & 61,00 & 0,32 \\
80 & 61,00 & 0,32 \\
80 & 63,00 & 0,32 \\
80 & 63,00 & 0,32 \\
80 & 63,00 & 0,32 \\
80 & 63,00 & 0,32 \\
80 & 61,00 & 0,32 \\
80 & 61,00 & 0,32 \\
80 & 61,00 & 0,32 \\
80 & 61,00 & 0,32 \\
\hline
\end{tabular}

Table 3 shows that when the generator is loaded in the form of a resistor, the frequency generated by the generator is $80 \mathrm{~Hz}$, while the expected frequency from the generator is $50 \mathrm{~Hz}$.

\subsection{Generator testing with $L$ load}

The test was conducted by installing a load $\mathrm{L}$ on the micro hydro generator without using an apparent load. The test results are shown in Table 4.

Table 4. Test results with L load

\begin{tabular}{ccc}
\hline $\begin{array}{c}\text { Frequency } \\
(\mathrm{Hz})\end{array}$ & $\begin{array}{c}\text { Voltage } \\
(\mathrm{V})\end{array}$ & $\begin{array}{c}\text { Current } \\
(\mathrm{A})\end{array}$ \\
\hline 108 & 85,00 & 0,72 \\
108 & 89,00 & 0,72 \\
108 & 89,00 & 0,32 \\
108 & 89,00 & 0,32 \\
108 & 89,00 & 0,32 \\
108 & 89,00 & 0,32 \\
108 & 89,00 & 0,32 \\
108 & 89,00 & 0,32 \\
108 & 89,00 & 0,32 \\
108 & 85,00 & 0,32 \\
108 & 85,00 & 0,32 \\
\hline
\end{tabular}

From Table 4 it is shown that with inductance loading, the value of the frequency generated by the generator is greater than the load R, which is $108 \mathrm{~Hz}$. It is still far from the desired result of $50 \mathrm{~Hz}$.

\subsection{Generator testing with load $\mathrm{C}$}

The test was performed by installing a $\mathrm{C}$ load on the micro hydro generator without using an apparent load. The test results are shown in table 5.

Table 5. Test results with $\mathrm{C}$ load

\begin{tabular}{ccc}
\hline $\begin{array}{c}\text { Frequency } \\
(\mathrm{Hz})\end{array}$ & $\begin{array}{c}\text { Voltage } \\
(\mathrm{V})\end{array}$ & $\begin{array}{c}\text { Current } \\
(\mathrm{A})\end{array}$ \\
\hline 83 & 75,00 & 0,74 \\
83 & 75,00 & 0,72 \\
83 & 75,00 & 0,72 \\
83 & 75,00 & 0,72 \\
83 & 75,00 & 0,72 \\
83 & 75,00 & 0,72 \\
83 & 77,00 & 0,72 \\
83 & 77,00 & 0,74 \\
83 & 77,00 & 0,74 \\
83 & 77,00 & 0,74 \\
83 & 75,00 & 0,74 \\
\hline
\end{tabular}

Table 5 shows that the resulting frequency value is not in accordance with the desired frequency, namely $83 \mathrm{~Hz}$.

\subsection{Generator testing with $R$ load and dummy load as frequency regulator}

The test was performed by connecting the generator to the load $\mathrm{R}$ and the apparent load which was set automatically using Arduino. The test results are shown in Table 6.

Table 6. Test results with apparent load and load R

\begin{tabular}{ccc}
\hline $\begin{array}{c}\text { Frequency } \\
(\mathrm{Hz})\end{array}$ & $\begin{array}{c}\text { Voltage } \\
(\mathrm{V})\end{array}$ & $\begin{array}{c}\text { Current } \\
(\mathrm{A})\end{array}$ \\
\hline 51 & 37,00 & 0,11 \\
51 & 37,00 & 0,11 \\
51 & 37,00 & 0,11 \\
51 & 37,00 & 0,11 \\
51 & 35,00 & 0,11 \\
51 & 35,00 & 0,11 \\
51 & 35,00 & 0,11 \\
51 & 35,00 & 0,11 \\
51 & 37,00 & 0,11 \\
51 & 37,00 & 0,13 \\
51 & 37,00 & 0,13 \\
\hline
\end{tabular}


From Table 6, it is shown that with the addition of the dummy load which is automatically regulated, the output frequency of the microhydro generator is close to the frequency value of the grid, which is $51 \mathrm{~Hz}$.

\subsection{Testing the generator with $L$ load and apparent load as a frequency regulator}

The test was conducted by L loading at the generator output and connected to an apparent load which was set automatically. The test results are shown in Table 7.

Table 7. Test results with apparent load and load L.

\begin{tabular}{ccc}
\hline $\begin{array}{c}\text { Frequency } \\
(\mathrm{Hz})\end{array}$ & $\begin{array}{c}\text { Voltage } \\
(\mathrm{V})\end{array}$ & $\begin{array}{c}\text { Current } \\
(\mathrm{A})\end{array}$ \\
\hline 52 & 31,00 & 0,05 \\
52 & 31,00 & 0,05 \\
52 & 33,00 & 0,05 \\
52 & 33,00 & 0,05 \\
52 & 33,00 & 0,05 \\
52 & 33,00 & 0,05 \\
52 & 33,00 & 0,05 \\
52 & 33,00 & 0,05 \\
52 & 33,00 & 0,05 \\
52 & 33,00 & 0,05 \\
52 & 33,00 & 0,05 \\
\hline
\end{tabular}

From Table 7, it is shown that with the addition of dummy-load, the frequency value is close to the PLN grid frequency value, which is $52 \mathrm{~Hz}$. It indicates that the apparent load can improve the output of the micro hydro generator.

\subsection{Testing the generator with $\mathrm{C}$ load and dummy load as a frequency regulator}

The test was conducted by loading $\mathrm{C}$ at the generator output and connected to an apparent load which is set automatically. The test results are shown in Table 8.
Table 8. Test results with apparent load and C load

\begin{tabular}{ccc}
\hline $\begin{array}{c}\text { Frequency } \\
(\mathrm{Hz})\end{array}$ & $\begin{array}{c}\text { Voltage } \\
(\mathrm{V})\end{array}$ & $\begin{array}{c}\text { Current } \\
(\mathrm{A})\end{array}$ \\
\hline 51 & 37,00 & 0,21 \\
51 & 37,00 & 0,21 \\
51 & 37,00 & 0,21 \\
51 & 37,00 & 0,21 \\
51 & 39,00 & 0,21 \\
51 & 39,00 & 0,21 \\
51 & 39,00 & 0,21 \\
51 & 39,00 & 0,21 \\
51 & 39,00 & 0,21 \\
51 & 39,00 & 0,23 \\
51 & 39,00 & 0,23 \\
\hline
\end{tabular}

From Table 8, it is presented that with the addition of the dummy-load, the frequency value is close to the PLN grid frequency value, which is $51 \mathrm{~Hz}$. It shows that the dummy-load can improve the output of the micro hydro generator.

When viewed as a whole, the addition of a dummy load which is automatically regulated can adjust the value of the generator frequency to close to the PLN grid frequency, which is 50 $\mathrm{Hz}$. It is much better when compared to a micro hydro generator that is not connected to a dummy load where the resulting frequency is in the range $80 \mathrm{~Hz}-108 \mathrm{~Hz}$.

\section{Conclusion}

This research has succeeded in making a micro-hydro generator prototype with automatic frequency control using the Arduino UNO as a control center. The output frequency of the micro hydro generator is close to the frequency of the PLN grid, which is $51 \mathrm{~Hz}-52$ Hz. Monitoring of micro hydro generator parameters has also displayed the reading value from the Arduino UNO.

\section{References}

Abdullah Nasir, B. (2013). Design and Implementation of Micro-Hydro-Electric Power Station. International Journal of 
Advanced Technology and Engineering Exploration, Vol. 2, No. 5, 39-47.

Ali M., Djalal M. R., Fakhrurozi M., Kadaryono, Budiman, Ajiatmo D. (2018). Optimal Design Capacitive Energy Storage (CES) for Load Frequency Control in Micro Hydro Power Plant Using Flower Pollination Algorithm. Electrical Power, Electronics, Communications, Controls and Informatics Seminar, EECCIS 2018.

Andik, M, Farul, M, Cahyono, I, Rukslin, R. (2018). Optimasi Load Frequency Control (LFC) Pada Sistem Pembangkit Listrik Tenaga Mikro Hidro Berbasis PID-ANFIS. Jurnal Rekayasa Mesin, Vol. 9, No. 1, 61-64.

Djalal, M, Setiadi, H, Imran, A. (2017). Frequency stability improvement of micro hydro power system using hybrid SMES and CES based on Cuckoo search algorithm. Journal of Mechatronics, Electrical Power, and Vehicular Technology, Vol. 8, No. 2, 76-84.

Djalal M. R., Yunus M.,Imran A.,Setiadi H. (2018). Capacitive Energy Storage (CES) Optimization For Load Frequency Control in Micro Hydro Power Plant Using Imperialist Competitive Algorithm (ICA). EMITTER International Journal of Engineering Technology, Vol. 5, No. 2, 279-297.

Hafid, A. (2021). Simulasi Pengendali Beban Elektronik untuk Pembangkit Listrik Mikrohidro (PLTMH) Desa Pallawa Kecamatan Tellu Limpoe Kapubaten Bone Provinsi Sulawesi Selatan. Jurnal Electrical and System Control Engneering, Vol. 4 No. 2, 87-94.

Jasa, L, Heri, M. (2010). Aplikasi Neural Network pada Sistem control turbin Mikrohidro. Lontar Komputer : Jurnal Ilmiah Teknologi Informasi, Vol. 1 No. 1, 67-75.

Kamble S. V., Akolkar S. M. (2018). Load frequency control of micro hydro power plant using fuzzy logic controller. Proceeding IEEE International Conference on Power, Control, Signals and Instrumentation Engineering, ICPCSI 2017.

Marliansyah, R, Putri, D, Khootama, Hermansyah, H. (2018). Optimization potential analysis of microhydro power plant (MHPP) from river with low head. 5th International Conference on Energy and Environment Research, ICEER 2018 - Prague, Czech Republic.

Márqueza, J, Molinab, M, Pacasc, J. (2010). Dynamic modeling, simulation and control design of an advanced microhydro power plant for distributed generation applications. International Journal of Hydrogen Energy, Vol. 35, No. 11, 5772-5777.

Nongdhar, D. (2017). Design of Electronic Load Controllers of Induction Generators used in Micro Hydro Power Schemes. $A D B U$ Journal of Electrical and Electronics Engineering (AJEEE), Vol. 1, No. 1, 24-27.

Qian D., Tong S., Liu X. (2015). Load Frequency Control for Micro Hydro Power Plants by Sliding Mode and Model Order Reduction. Journal for Control, Measurement, Electronics, Computing and Communications, Vol. 56, No. 3, 318-330.

Raja Singh, R, B. Anil Kumar, D, Shruthi, Panda, R, Thanga Raj. (2018). Review and experimental illustrations of electronic load controller used in standalone Micro-Hydro generating plants. Engineering Science and Technology, Vol. 21, No. 5, 886-900.

Nikhila Sanampudi, P. Kanakasabapathy. (2021). Integrated voltage control and frequency regulation for stand-alone micro-hydro power plant, Materials Today: Proceedings.

Wube, A. (2016). Design and Analysis of Small Hydro Power for Rural Electrification. Global Journal of Researches in Engineering: $F$ Electrical and Electronics Engineering, Vol. 16, No. 6, 25-46. 